\title{
Understanding the Intentions of Accounting Students to Pursue Career as a Professional Accountant
}

\author{
Kiky Srirejeki'; Saras Supeno²; Agus Faturahman ${ }^{3}$ \\ ${ }^{1-3}$ Department of Accounting, Faculty of Economic and Business, Universitas Jenderal Soedirman \\ Jln. Profesor DR. HR Boenyamin No. 708, Purwokerto Utara 53122, Indonesia \\ ${ }^{1}$ kikysrirejeki@gmail.com; ${ }^{2}$ sarassupeno.feb@gmail.com; \\ 3agusfaturohman.feb@gmail.com
}

Received: $21^{\text {st }}$ December 2018/ Revised: $7^{\text {th }}$ February 2019/ Accepted: $13^{\text {th }}$ February 2019

How to Cite: Srirejeki, K., Supeno, S., \& Faturahman, A. (2019). Understanding the Intentions of Accounting Students to Pursue Career as a Professional Accountant. Binus Business Review, 10(1), 11-19. https://doi.org/10.21512/bbr.v10il.5232

\begin{abstract}
The aim of this research was to investigate the contributing factors that influenced the intentions of accounting students in Indonesia to pursue a career as a professional accountant. The researchers applied a quantitative method to present a descriptive analysis of accounting students perception. The researchers collected 439 questionnaires from accounting students across universities in Indonesia with simple random sampling technique. The findings show that the intrinsic factor (attitude) and parental or peers influence (subjective norm) affect the students' intention to pursue a career as a professional accountant. The results of this research are expected to give insights to university's accounting department and professional bodies such as Institute of Indonesia Chartered Accountant and Institute of Certified Public Accountant to formulate strategies to achieve the desired number of accountants in Indonesia. In addition, regulatory agencies can use these findings as a basis to develop policies that guide universities or professional bodies to make the accounting profession more desirable.
\end{abstract}

Keywords: students intention, accounting students, professional accountant

\section{INTRODUCTION}

Several data sources such as the Pangkalan Data Pendidikan Tinggi (PDPT - Indonesia Higher Education Database) and the World Bank mention that among ASEAN countries, Indonesia has the largest number of accounting students and graduates. However, when it comes to the number of professional accountants, the case is different. Data from the Institute of Ikatan Akuntan Indonesia (IAI - Indonesia Chartered Accountant) shows that the number of professional accountants in Indonesia is far behind Thailand, Malaysia, and Singapore. The professional accountant in here is an accountant who gets official professionalism recognition by holding professional accountant certification (Ikatan Akuntan Indonesia, 2017).

According to data from the PDPT, in 2016, Indonesia had 265.000 accounting students from 589 universities. The World Bank also stated that in 2014, on average, ASEAN countries produced 77.300 accounting graduates annually. From that number, Indonesia contributed $45 \%$ or an average of 35.000 accounting graduates each year (World Bank Group, 2014).

In 2016 economic census from Badan Pusat Statistik (BPS - Statistics Central Agency) showed that Indonesia had a total of 26,7 million companies. If the researchers categorize the data according to the business scale, a total of 26,26 million businesses are on the scale of Micro, Small and Medium Enterprises (MSMEs) or equal to $98,33 \%$. Then, 450.000 companies are large medium enterprises (Badan Pusat Statistik, 2017).

Data from the Indonesia Stock Exchange also shows that in October 2017, there were 558 public companies in Indonesia which were required to be audited in each year. The data show that Indonesia has an enormous market for professional accountants for conducting financial report audits, special audits, financial report review, as well as compilation services, taxation and consultation. Not to mention, there are 
also the needs for accounting services for government organizations, non-profit organizations, cooperatives, and foundations.

Despite the fact of the immense needs of professional accounting service, which means the demands of professional accountants, data from IAI show different things about the availability of professional accountants in Indonesia. Based on the data in 2016, the number of professional accountants was only 28.110 . This number is far below Indonesia's neighboring countries such as Thailand with 71.128 professional accountants, Singapore with 31.118 professional accountants, and Malaysia with 32.990 professional accountants. If the researchers compare the number of accountants to the total population, Indonesia is the lowest among the five ASEAN countries.

Table 1 shows that the gap ratio between the professional accountants and the total population in Indonesia is the highest. By comparison, in 9.289 people, only one person becomes a professional accountant. It is a very different condition compared to Malaysia that from 945 people, there is one person who is a professional accountant.

Table 1 Comparison of Number of Accountants with Total Population

\begin{tabular}{clccc}
\hline No & Country & $\begin{array}{c}\text { Total } \\
\text { Number of } \\
\text { Accountants }\end{array}$ & $\begin{array}{c}\text { Total } \\
\text { population }\end{array}$ & $\begin{array}{c}\text { Accountant } \\
\text { Ratio: Total } \\
\text { population }\end{array}$ \\
\hline 1 & Singapore & 31.118 & 5.607 .000 & $1: 180$ \\
2 & Malaysia & 32.990 & 31.190 .000 & $1: 945$ \\
3 & Thailand & 71.128 & 68.860 .000 & $1: 968$ \\
4 & Philippines & 19.573 & 103.300 .000 & $1: 5278$ \\
5 & Indonesia & 28.110 & 261.100 .000 & $1: 9289$ \\
\hline & & 182.919 & 470.057 .000 & $1: 2570$ \\
\hline
\end{tabular}

(Source: Asean Federation of Accountant, 2016; World Bank Group, 2016)

Many researchers have examined various aspects of students' intention to pursue careers in accounting. The research conducted by Jackling and Calero (2006) is a reference for subsequent research analyzing the intentions of accounting students to become professional accountants. They examined the factors that influenced accounting students in Australia to pursue a career as a professional accountant. The results suggested that the role of the accounting lecturer was crucial in shaping student opinions about the importance of a career as a professional accountant, especially for early students. There was a process of creating the mindset during the learning period that the lecturer had a dominant role. Furthermore, they suggested that the internal factors, passion, or genuine interest in accounting influenced the intention of students to become professional accountants rather than external factors.

Then, Sugahara, Hiramatsu, and Boland (2009) analyzed the intentions of accounting students in Japan to pursue a career as a Certified Public Accountant (CPA). The results concluded that education and experience affected students' intention to become CPA. It meant that students who studied accounting and those who had working experience related to accounting had a higher intention to be CPA than students who did not study accounting and had no working experience related to accounting.

Other research in China was carried out by Wen, Hao, and $\mathrm{Bu}$ (2015). They replicated research from Jackling and Calero (2006). They suggested that both internal factors such as interest in accounting, and external factors such as the influence of family, friends, and lecturers affected the intention of accounting students to pursue the career as CPA.

Similarly, Jaffar, Ismail, and Zahid (2015) studied the accounting students in Malaysia and reported that the combination of environmental factors, individuals, and academic institutions influenced the preferences of accounting students to pursue a career as a chartered accountant. Then, El-Mousawi and Charbaji (2016) stated that social pressure affected students' intentions to pursue a career as a CPA.

In Indonesia, similar research has also been carried out by several researchers even though the sample is still limited. They also focus on only one or several universities in the same area. Harnovinsah (2017) examined the intentions of accounting students from several universities in Jakarta. The result showed that the career choices of accounting students were determined by the expectations and opportunities that would be obtained by the career. Then, Sari (2014) examined the accounting students at one university. The result suggested that financial rewards, professional training, professional recognition, social values, work environment, and labor market influenced the interest of students to be a public accountant simultaneously. Meanwhile, Priyanti, Herawati, and Sinarwati (2017) agreed that six factors influenced student intention to have a career as an accountant. Those were professionalism, intrinsic value, financial, personal, professional recognition, and professional training.

From the previous research, both intrinsic and extrinsic factors are strong predictors to the students' intention to pursue a future career. However, the research can infer that the intrinsic factors are more dominant in influencing the intention of students to pursue a future career as a professional accountant compared to extrinsic factors.

This research uses the Theory of Planned Behavior (TPB) as a basic theory. TPB is often used to explain the phenomenon of behavior and attitude. TPB is an extension of the Theory of Reasoned Action (TRA) which was coined by Martin Fishbein and Icek Ajzen in 1975. TPB is an extension of TRA because it considers the control of behavior that is intensified by someone in addition to the attitude and subjective 
norm factors which already stated in TRA. In TPB, the occurrence of intention to behave is determined by three factors. First, behavioral belief is the individual's belief in the results of behavior and the evaluation of the results. Second, normative belief is the belief on the normative expectations of others and the motivation to fulfill these expectations. Third, control belief is the existence of things that support or inhibit the behavior that will be displayed and the intensity of how strong things that support and hinder its behavior.

Sequentially, TPB explains that behavioral belief results in an attitude toward positive or negative behavior. Then, normative beliefs will generate social pressure, or subjective norm and control beliefs will give rise to perceived behavioral control (Ajzen, 2002).

This research particularly wants to examine the intention of accounting student to pursue a career as a professional accountant. To assess how the intentions of accounting students towards the professional accounting profession, the researchers employ TPB. TPB is considered a well-established theory to explain the prediction of behavior (Wen et al., 2015). In the context of this research, there are three tested variables according to the TPB components. Those are attitude, subjective norm, and perceived behavioral control.

Previous research concludes that attitude will influence behavior. Jackling and Calero (2006) stated that intrinsic and extrinsic factors influenced attitudes. For example, intrinsic factors could be satisfaction with a job, the opportunity to be creative and independent, intellectual challenges to be faced, and career development. Moreover, Demagalhaes, Wilde, and Fitzgerald (2011) mentioned that career development was a factor that influenced someone to pursue a specific career. This statement is also supported by Ng, Chong, H'ng, Khor, and Ng (2013) stating that career development influenced career choice preferences in the future.

Similarly, Dibabe, Wubie, and Wondmagegn (2015) found that job opportunity had a positive effect on students' career choice in accounting. Baldacchino, Tabone, Micallef, and Grima (2018) suggested that job autonomy was an important motivator for individuals to consider auditor as a career. From the explanation, the first hypothesis is as follows:

H1 : Accounting students who believe that the professional accountants offer a good career development will tend to choose a career as a professional accountant.

In this research, the dimensions of attitude variables are also related to financial rewards. Several previous researchers have concluded varying results on the effect of financial rewards on student career intentions to be an accountant. Byrne, Willis, and Burke (2012) showed the significant influence of financial rewards. However, Jackling and Calero (2006), Law (2010), Wen et al. (2015), and Pratama (2017) suggested that financial rewards were not important factors that determined a person in choosing a career as a professional accountant. This tendency towards financial rewards also varies depending on the region. In the United States and Japan, financial reward is an important factor (Suhagara et al., 2009), but in Canada and Hong Kong, it is not (Law, 2010). Therefore, the researchers formulate the second hypothesis as follows:

H2 : Accounting students who believe that being a professional accountant can provide good financial rewards will tend to choose a career as a professional accountant.

The motivation for a career in an attractive field of work is also an important factor in the selection of career accounting students (Jackling and Calero, 2006). Recently, Santos and Almeida (2018) also found that personal attitude influenced graduated accounting students to pursue a career in accounting. Therefore, the third hypothesis is:

H3 : Accounting students who believe that the professional accountant is an exciting career will tend to choose a career as a professional accountant.

In subjective norm, according to TPB, social pressure affects a person in making decisions. Social pressure in TPB mainly comes from the closest people. Someone will listen to the opinions of his or her closest people and make it as a consideration. Jackling and Calero (2006) stated that the role of lecturers was very dominant in shaping students' opinions. Moreover, it ultimately affected their intention to become a professional accountant. Dalci and Özyapici (2018) found that a large power distance/collectivism country associated with parental and peers' influenced the students' intention in choosing the accounting career. In this research, the closest people are not only limited to lecturers but also parents and friends. From the explanation, the fourth hypothesis is:

H4: Accounting students, who believe that their closest people (parents, friends, lecturers) that it is good to have a career as a professional accountant, will tend to choose a career as a professional accountant.

Perceived behavioral control represents the degree of intention to ease or trouble someone in doing something. Wen et al. (2015) stated that the intention of accounting students on the difficulty of taking the CPA exam would affect them for a career as a CPA. Self-efficacy is a measurement in individuals' self-confidence in his or her ability that has a positive relationship in individuals' intention in becoming a CPA (Schoenfeld, Segal, \& Borgia, 2017). In more recent research, Owusu, Obeng, Ofori, Ossei Kwakye, and Bekoe (2018) reported that students' belief was significantly associated with their intention to pursue 
a CPA qualification. With the same analogy, the fifth hypothesis is:

H5 : Accounting students who believe it is difficult to have a career as a professional accountant will not tend to have a career as a professional accountant.

Based on the explanation, there are a phenomenon gap and research gap which motivates us to analyze further in this research. The phenomenon gap is related to the fact that Indonesia as an emerging economy has promising economic potential. With good and growing economic opportunities, Indonesia is the target of investment for many potential investors locally and globally. The increased investment will open a new business. New emerging business requires professional accounting services. Starting from the early stages of a business, professional accountants are needed as a consultant up to the service for taxation, tax planning, financial consulting, and audits. Then, the increase in business complexity and economy in Indonesia gives terrace for professional accounting services. Seeing the market demand of the professional accountant, the career as a professional accountant should be very interesting. Based on the data, the availability of prospective professional accountants in Indonesia is quite large. It is shown by the number of accounting students and graduates. It is in the top position among ASEAN countries. However, with the number of professional accountants in Indonesia, there is a large gap. It indicates that many accounting graduates do not pursue a career as professional accountants.

Previous researchers have examined the students' intention to pursue a career in accounting. However, they have not conducted the large samples. Therefore, the results are still fragmented. The result of the research is varied as well. This reason, in particular, becomes the research gap. The researchers want to fill this gap by using a larger sample. The researchers also survey accounting students across various universities in Indonesia both in state and private universities.

Therefore, this research aims to investigate what factors influence Indonesia accounting students' intention to pursue a career as a professional accountant. The results are expected to contribute to the existing literature in this field and give a more comprehensive reality of the intentions of accounting students to pursue a career as a professional accountant.

\section{METHODS}

The researchers apply a quantitative research design approach. The researchers use a survey method with a sample of accounting students from both private and state universities from various regions in Indonesia using an online questionnaire. Moreover, the online questionnaire is used because it offers a broader range of samples with cheaper cost than regular questionnaires. The researchers use simple random sampling and distribute the questionnaires to accounting students from many universities in Indonesia. In total, 439 questionnaires are collected within two weeks, and all of them are valid for the research.

The question items used in this research adopt questions from Wen et al. (2015). The question items have been adjusted, and little modifications have been made regarding language usage. The initial questionnaire is in English, but for this research, the question is presented in bahasa Indonesia. To test the research hypotheses, the researchers employ a binary logistic regression model. The dependent variable (intention to pursue a career as a professional accountant) is created for binary logistic regression analysis based on its dichotomous nature. It is recorded as 1 when respondents answered "yes" to the survey question "do you have an intention to pursue a career as a professional accountant?" and it is 0 if the answer is "no" or "do not know". There is one control variable included in the empirical model (gender). Gender is a dummy variable, which is equal to 1 for male student and 2 for a female student.

Besides the control variable, the researchers include five independent variables from the questionnaire. First, career prospect measures the perceived career advancement of the professional accountant. Respondents express their feelings about the statement that "professional accountant would give them career development." Second, financial reward is to measure the perceived financial condition or earnings potential brought by a professional accountant. Respondents express their feelings about the statement that "professional accountant would have better long-term earnings potential." Third, interest is to measure personal interest in the job of a professional accountant. Respondents express their feelings about the statement that "professional accountant is an interesting job."

Fourth, the subjective norm is to measure the external influence over a respondent's choice to pursue a career as a professional accountant. Respondents express their feelings about the statement of "people who are important to me (i.e., parents, friends, lecturers) think I should pursue a career as a professional accountant." Fifth, perceived behavioral control is to measure the perceived difficulties in pursuing a career as a professional accountant. Respondents express their feeling about the statement that "it is difficult for me to be a professional accountant." The logistic model is as follow:

$$
\begin{gathered}
\operatorname{Ln}[p /(1-p)]=\beta 0+\beta 1 * \text { Career Prospect }+ \\
\beta 2 * \text { Financial Reward }+ \\
\beta 3 * \text { Interest }+ \\
\beta 4 * \text { Subjective Norm }+ \\
\beta 5 * \text { Perceived Behavioral Control }+ \\
\beta 6^{*} \text { Gender }+\mu
\end{gathered}
$$


It shows that $\mathrm{p}$ is the probability of respondents with an intention to pursue a career as a professional accountant; $\beta 0$ is the constant (y-intercept); $\beta 1-5$ is the slope coefficient; $\beta 6$ (gender) is the control variables; and $\mu$ is the error term. Table 2 provides a summary of all five independent variables and one control variable.

Table 2 Variable and Indicator Measurements

\begin{tabular}{|c|c|c|c|}
\hline Hypothesis & Key indicator & $\begin{array}{l}\text { Corresponding } \\
\text { variable }\end{array}$ & Measurement \\
\hline H1 & $\begin{array}{l}\text { Career } \\
\text { prospect }\end{array}$ & Career & \multirow{5}{*}{$\begin{array}{l}\text { Measured by } \\
\text { 7-point Likert } \\
\text { scales (seven } \\
\text { for "Strongly } \\
\text { agree" and one } \\
\text { for "strongly } \\
\text { disagree." }\end{array}$} \\
\hline $\mathrm{H} 2$ & $\begin{array}{l}\text { Financial } \\
\text { reward }\end{array}$ & Financial & \\
\hline $\mathrm{H} 3$ & Interesting job & Interest & \\
\hline $\mathrm{H} 4$ & $\begin{array}{l}\text { Influence of } \\
\text { important } \\
\text { people }\end{array}$ & Subjective norm & \\
\hline H5 & Difficulty & $\begin{array}{l}\text { Perceived } \\
\text { behavioral } \\
\text { control }\end{array}$ & \\
\hline $\begin{array}{l}\text { Control } \\
\text { Variable }\end{array}$ & Gender & $\begin{array}{l}\text { Gender, dummy } \\
\text { variable }\end{array}$ & $\begin{array}{l}\text { Equals to } \\
\text { one for male } \\
\text { student and } \\
\text { two for female } \\
\text { student. }\end{array}$ \\
\hline
\end{tabular}

\section{RESULTS AND DISCUSSIONS}

The researchers receive 439 respondents from across universities in Indonesia. Table 3 reports the respondent's university origin. It shows that the respondents are dispersed across universities in Indonesia, both from state and private universities. In summary, there are 330 respondents from state universities, and the rest is from private universities.

Table 4 reports descriptive statistics of the demographic respondents' information. From Table 4, the researchers can conclude that 343 of 439 respondents are female students. This information suggests that female is more likely to take an accounting course than male.

Table 5 shows the descriptive statistics of six variables among 153 students who do not want to be a professional accountant. Meanwhile, in Table 6, it explains the descriptive statistics of six variables among 286 students who want to pursue a career as a professional accountant.

Variable of career prospect has the mean value of 5,1950 in Table 5 and the mean value of 5,9586 in Table 6. It seems that the respondents both who have an intention to pursue a career as a professional accountant and those who do not perceive that a professional accountant has good career prospect. Then, the variable of financial has the mean value of 5,8922 in Table 5 and the mean value of 6,3741 in Table 6. The higher mean value for students who want to pursue a career as a professional accountant shows that they perceive a professional accountant give a more financial reward. Variable of interest has the mean value of 4,8170 in Table 5 and the mean value of 5,4336 in Table 6. Moreover, the variable of the subjective norm has the mean value of 5,0044 in Table 5 and the mean value of 5,4233 in Table 6 . Last, the variable of perceived behavioral control has the mean value of 4,8366 in Table 5 and the mean value of 5,8322 in Table 6 .

Table 3 Respondents' Universities Origin

\begin{tabular}{|c|c|c|}
\hline University & Province & Respondents \\
\hline Universitas Airlangga & East Java & 15 \\
\hline Universitas Andalas & West Sumatera & 37 \\
\hline Universitas Bina Nusantara & DKI Jakarta & 18 \\
\hline Universitas Brawijaya & East Java & 10 \\
\hline Universitas Diponegoro & Central Java & 16 \\
\hline Universitas Gadjah Mada & Yogyakarta & 28 \\
\hline Universitas Hasanuddin & South Sulawesi & 31 \\
\hline Universitas Islam Indonesia & $\begin{array}{l}\text { Special Region of } \\
\text { Yogyakarta }\end{array}$ & 28 \\
\hline $\begin{array}{l}\text { Universitas Jenderal } \\
\text { Soedirman }\end{array}$ & Central Java & 40 \\
\hline $\begin{array}{l}\text { Universitas Lambung } \\
\text { Mangkurat }\end{array}$ & South Kalimantan & 12 \\
\hline Universitas Lampung & Lampung & 17 \\
\hline $\begin{array}{l}\text { Universitas Muhammadiyah } \\
\text { Magelang }\end{array}$ & Central Java & 34 \\
\hline $\begin{array}{l}\text { Universitas Muhammadiyah } \\
\text { Malang }\end{array}$ & East Java & 20 \\
\hline Universitas Mulawarman & East Kalimantan & 13 \\
\hline Universitas Negeri Jakarta & $\begin{array}{l}\text { Special Capital Region } \\
\text { of Jakarta }\end{array}$ & 23 \\
\hline Universitas Negeri Manado & North Sulawesi & 14 \\
\hline $\begin{array}{l}\text { Universitas Negeri } \\
\text { Yogyakarta }\end{array}$ & $\begin{array}{l}\text { Special Region of } \\
\text { Yogyakarta }\end{array}$ & 35 \\
\hline Universitas Padjajaran & West Java & 25 \\
\hline Universitas Sumatera Utara & North Sumatra & 8 \\
\hline Universitas Syiah Kuala & Special Region of Aceh & 6 \\
\hline Universitas Yapis Papua & Papua & 9 \\
\hline Total & & 439 \\
\hline
\end{tabular}

Table 4 Descriptive Statistics of Demographic Respondents $(\mathrm{n}=439)$

\begin{tabular}{lccc}
\hline Gender & Female & Male & Total \\
\hline Number & 343 & 96 & 439 \\
Percentage (\%) & 78,1 & 21,9 & 100 \\
Intention to pursue career & Yes & No & \\
Professional accountant & & & \\
Number & 286 & 153 & 439 \\
Percentage (\%) & 65,1 & 34,9 & 100 \\
\hline
\end{tabular}


Table 5 Descriptive Statistics of Independent Variables for Students Who Do Not Want to be a Professional Accountant $(n=153)$

\begin{tabular}{lcc}
\hline Variables & Mean & $\begin{array}{c}\text { Standard } \\
\text { Deviation }\end{array}$ \\
\hline Career & 5,1950 & 0,10878 \\
Financial & 5,8922 & 0,13090 \\
Interest & 4,8170 & 0,13356 \\
Subjective norm & 5,0044 & 0,11767 \\
Perceived behavioral control & 4,8366 & 0,11701 \\
\hline
\end{tabular}

Table 6 Descriptive Statistics of Independent Variables for a Student Who Wants to be a Professional Accountant $(n=286)$

\begin{tabular}{lcc}
\hline Variables & Mean & $\begin{array}{c}\text { Standard } \\
\text { Deviation }\end{array}$ \\
\hline Career & 5,9586 & 0,03792 \\
Financial & 6,3741 & 0,04471 \\
Interest & 5,4336 & 0,07927 \\
Subjective Norm & 5,4233 & 0,06263 \\
Perceived Behavioral Control & 5,8322 & 0,04440 \\
\hline
\end{tabular}

The result of the logistic regression model is reported in Table 7. The logistic regression model is used to determine the extent to which the independent variables measure the probability of pursuing a career as a professional accountant by respondents (yes $=1$; no $=0$ ).
Before analyzing the regression result, the researchers examine the appropriateness of the logistic regression model. The researchers use Hosmer and Lemeshow Chi-square test of goodness of fit as the indicator. The result of the research (Table 7) shows that Hosmer and Lemeshow Chi-square is 17,080, degrees of freedom (df) is 8 , and p-value is 0,029 . The statistics also illustrates the Omnibus test that the Chisquare of the model is 115,875 with df of 5 and the $\mathrm{p}$-value of 0,000 . This result shows that the overall model is significant with all included five independent variables in the model.

Another good predictor to assess the model's overall appropriateness is the Nagelkerke R2. In this research, the Nagelkerke R2 is equal to 0,320 . The Cox and Snell R2 measure an estimation of the variance that can be predicted from the combination of all interdependent variables2. The result shows the Cox and Snell R2 is equal to 0,232. These results mean that there is an adequate fit of the data to the logistic regression model. It also implies that one or more of the independent variables can significantly explain or predict the dependent variable.

From Table 7 , the researchers can conclude that the variables of interest and subjective norm are insignificant. These reports show that $\mathrm{H} 3$ and $\mathrm{H} 4$ are not supported. The insignificant relationship between interest and intention to pursue a career as a professional accountant is contradictory to most research surveying that interest as an influential factor in student's career decisions (Ahmed, Alam, \& Alam, 1997; Wen et al., 2015). In Indonesia, that is not the case. The different location research setting may contribute to this finding even though this proposition should be investigated

Table 7 Logistic Regression Statistics

Predicting the Intention to Pursue a Career as a Professional Accountant $(n=439)$.

\begin{tabular}{|c|c|c|c|c|c|c|}
\hline & B & S.E & Wald & $\mathrm{df}$ & Sig & $\operatorname{Exp}(B)$ \\
\hline \multicolumn{7}{|l|}{ Control Variable } \\
\hline Gender & 0,128 & 0,285 & 0,204 & 1 & 0,652 & 1,137 \\
\hline \multicolumn{7}{|l|}{ Independent variables } \\
\hline Career & 0,977 & 0,250 & 15,230 & 1 & $0,000^{* * *}$ & 2,656 \\
\hline Financial & $-0,865$ & 0,199 & 18,815 & 1 & $0,000^{* * *}$ & 0,421 \\
\hline Interest & $-0,046$ & 0,138 & 0,111 & 1 & 0,739 & 0,955 \\
\hline Subjective Norm & $-0,015$ & 0,173 & 0,008 & 1 & 0,929 & 0,985 \\
\hline Perceived Behavioral Control & 0,961 & 0,162 & 35,318 & 1 & $0,000^{* * *}$ & 2,615 \\
\hline Constant & $-4,680$ & 1,019 & 21,090 & 1 & $0,000^{* * *}$ & 0,009 \\
\hline$-2 \log$ likelihood & 451,774 & & & & & \\
\hline Cox and Snell R ${ }^{2}$ & 0,232 & & & & & \\
\hline Nagelkerke $\mathrm{R}^{2}$ & 0,320 & & & & & \\
\hline Hosmer and Lemeshow test & 0,029 & & & & & \\
\hline Correct classification rate (\%) & 75,4 & & & & & \\
\hline
\end{tabular}


further. The research location is done by Ahmed et al. (1997) in New Zealand, Sugaraha et al. (2009) in Japan, and Wen et al. (2015) in China. If those research location differences are seen, the previous research is conducted in more developed countries compared to Indonesia. Students in developed countries may have more career alternatives so that they can choose the career that interests them the most.

The variable of the subjective norm is also found to be insignificant with the intention to pursue a career as a professional accountant. This result suggests that influence or pressure from families, friends, and lecturers may not encourage students to pursue a career as professional accountants. This finding may give insight into how Generation $Z$ (the respondents) responds to the external pressure. Generation $\mathrm{Z}$ also was known as Gen Z or iGeneration is the demographic cohort after the Millenials, they are born after 1995. In response to the insignificant subjective norm variable, it may be related to the Generation $\mathrm{Z}$ characteristics. Generation Z, compared to Millenials, seems to be spending more time away from their parents. Ragusa (2017) reported that the percentage of ate meals together as families in Generation $\mathrm{Z}$ drop to $52 \%$ compared to their previous generation, Millennials $(64 \%)$. This result suggested that Generation $\mathrm{Z}$ did not spend much time together with their families. In this sense, the influence of family (parents) might not be as strong as for the previous generation.

$\mathrm{H} 1$ and $\mathrm{H} 2$ predict that career prospect and financial reward are significant variables to intention. Table 7 shows that both hypotheses are supported. The variables of career prospect, financial, and perceived behavioral control are significant at less than $1 \%$. The coefficient of career prospect is 0,977 and significant at less than $1 \%$. It suggests that the respondents perceive professional accountant have a good career prospect. Meanwhile, variable of financial is negative and significance at less than 1\% (regression coefficient $=-0,865$ and Wald-test-statistic $=18,815)$. It indicates that financial is significance in shaping the intention to pursue a career as a professional accountant. This result is not in a way that the researchers predict. This finding supports the previous research by Ahmad, Ismail, and Anantharaman (2015) that the sole focus on extrinsic rewards was not enough to guarantee commitment towards the profession from accounting students. Research shows that when it comes to money or financial motivation, Generation $\mathrm{Z}$ is not as freaked out as the previous generation (Ragusa, 2017). Generation $Z$ tends to avoid debt and save more money since childhood. It makes them understand their financial condition. However, future research is needed to confirm this allegation.

H5 suggests that perceived behavioral control, regarding difficulties to pursue a career as a professional accountant, may prevent students from pursuing the career. The result shows a positive relationship between perceived behavioral control and intention to pursue a career as a professional accountant. It means that the more students perceive professional accountant as a challenging career is, the more likely the students will pursue a career as a professional accountant. Thus, H5 is not supported in a qualified way. This finding may also indicate that the respondents, which are Generation $\mathrm{Z}$, love to challenge themselves. The harder the job is, the more interesting it gets.

The researchers further analyze the findings by making interpretations of the probability ratio. It shows the change in the probability of the dependent variable. Meanwhile, the value of an independent variable adjusts by one unit. In the results, the coefficient of career prospect is 0,977 , and its probability ratio is $2,656[=\exp (0.977)]$. It indicates that the increase in every unit in the career prospect can increase the chance of respondents intention to pursue a career as a professional accountant by 2,656 .

The coefficient of financial is $-0,865$, and its probability ratio is $0,421[=\exp (-0,865)]$. It implies that the increase in every unit in the finance can decrease the probability in the respondents' intention to pursue a career as a professional accountant by 0,421 . Furthermore, it shows that the Indonesian accounting students who like a job with good financial reward are less to pursue a career as professional accountants. The coefficient of perceived behavioural control is 0,961 , and its probability ratio is $2,615 \quad[=\exp =(0,961)]$. This result indicates that the increase in every unit in the perceived behavioral control can increase the probability of the intention to pursue a career as a professional accountant by 2,616 . It means that the more difficult the job as perceived by students is, the more they want to choose a professional accountant as their careers.

The researchers also employ a control variable (gender) in this research. Based on Table 7, the coefficient of gender is positive but insignificant. These results indicate that female students are not significantly different from male students in their intention to pursue a career as a professional accountant.

\section{CONCLUSIONS}

The researchers find that career prospect, financial reward, and perceived behavioral control/ perceived difficulties as a professional accountant can significantly affect students' intention to pursue a career as a professional accountant. However, students' perceived financial reward of professional accountants negatively affects the student's choice to pursue a career as a professional accountant.

This research has a practical implication. Students perceived a professional accountant as a job that has a good career prospect. Students understand that being a professional accountant is not only merely work in a public accounting firm. A professional accountant can work in a diverse industry and company. Along with economic development and growth, more business arises, and the needs of an accountant also arise. Professional accountants are now actively involved in business development, management consulting, investment consulting, and tax planning. The job availability of a professional 
accountant is reserved, so accounting students perceive that being a professional accountant have a good future career prospect. The practical implication related to this finding is that universities can cooperate with public accounting firms, consulting companies, and financial-related government agencies to provide more internship opportunities for accounting students.

Second, the findings of the relationship between financial and perceived difficulties in intention to reveal the current phenomenon of Generation $\mathrm{Z}$. Although there is limited research about Generation $\mathrm{Z}$, several articles from business magazines can be used to analyze the findings. The respondents, which are categorized as Generation $\mathrm{Z}$, have a different perspective on money. It shows that Generation $\mathrm{Z}$ understands their financial condition better than Millenials. Generation $\mathrm{Z}$ tends to avoid debt and to save more money, so it makes them reserved for the financial situation. This research finds that financial is a negative significance to the intention to pursue a career as a professional accountant.

Furthermore, the result shows that Generation $\mathrm{Z}$ is also a challenger. It reveals that the harder the job is, the more interesting it will be to Generation $\mathrm{Z}$. Perceived difficulties of the professional accountant as a job trigger them to pursue the career as Singh and Dangmei (2016) reported that Generation Z looked for a job that allowed them to have enough independence so that they could prove themselves and earn immediate recognition.

Although the researchers have carefully planned and examined this research, and collected representative data from varies universities (state and private) across Indonesia, the result may not picture the whole description of Indonesia accounting students. Due to time constraint, the researchers only successfully collect 439 questionnaires. Future research may enlarge the sample basis and try to replicate this research by adding more variables that are more relevant to the Generation $\mathrm{Z}$ characteristics.

\section{REFERENCES}

Ahmad, Z., Ismail, H., \& Anantharaman, R. N. (2015). To be or not to be: An investigation of accounting students' career intentions. Education + Training, 57(3), 360-376.

Ahmed, K., Alam, K. F., \& Alam, M. (1997). An empirical study of factors affecting accounting students' career choice in New Zealand. Accounting Education, 6(4), 325-335.

Ajzen, I. (2002). Perceived behavioral control, self-efficacy, locus of control, and the theory of planned behavior. Journal of Applied Social Psychology, 32(4), 665683.

Asean Federation of Accountant. (2016). Annual Report 2016. Retrieved October $15^{\text {th }} 2017$ from www. aseanaccountant.org

Badan Pusat Statistik. (2017). Direktori awal usahal perusahaan skala menengah besar sensus ekonomi 2016. Retrieved from https:// www.bps.go.id/publication/2017/12/26/ a656763c4a6a019feafdf5a4/direktori-usahaperusahaan-menengah-besar-aktivitas-jasa-lainnyasensus-ekonomi-2016.html

Baldacchino, P. J., Tabone, N., Micallef, L. G., \& Grima, S. (2018). Drivers and drawbacks of an external auditing career. International Journal of Economics \& Business Administration (IJEBA), 6(3), 21-46.

Byrne, M., Willis, P., \& Burke, J. (2012). Influences on school leavers' career decisions-Implications for the accounting profession. The International Journal of Management Education, 10(2), 101-111.

Dalci, İ., \& Özyapici, H. (2018). Cultural values and students' intentions of choosing accounting career. Journal of Financial Reporting and Accounting, 16(1), 179-196.

Demagalhaes, R., Wilde, H., \& Fitzgerald, L. R. (2011). Factors affecting accounting students' employment choices: A comparison of students' and practitioners' views. Journal of Higher Education Theory and Practice, 11(2), 32-41.

Dibabe, T. M., Wubie, A. W., \& Wondmagegn, G. A. (2015). Factors that affect students' career choice in accounting: A case of Bahir Dar University students. Research Journal of Finance and Accounting, 6(5), 146-153.

El-Mousawi, H. Y., \& Charbaji, A. (2016). Becoming a CPA-How to attract university students to the accounting profession using theory of planned behavior? Open Journal of Accounting, 5(02), 9-18.

Harnovinsah. (2017). Career decision of accounting students and its influencing factors: A study of university accounting students in DKI Jakarta, Indonesia. International Journal of Finance and Accounting, $6(2), 59-65$.

Ikatan Akuntan Indonesia. (2017). Bersiap diri menyambut pasar tunggal Asean. Retrieved October $15^{\text {th }} 2017$ from http://iaiglobal.or.id/v03/berita-kegiatan/ detailarsip-617.

Jackling, B., \& Calero, C. (2006). Influences on undergraduate students' intentions to become qualified accountants: Evidence from Australia. Accounting Education: An International Journal, 15(4), 419-438.

Jaffar, N., Ismail, N., \& Zahid, S. M. (2015). Determinants of the accounting students' preference to practice as chartered accountant in Malaysia. Accountancy Business and the Public Interest, 2015, 43-59.

Law, P. K. (2010). A theory of reasoned action model of accounting students' career choice in public accounting practices in the post-Enron. Journal of Applied Accounting Research, 11(1), 58-73.

Ng, L. C., Chong, H. O., H'ng, C. K., Khor, P. H., \& Ng, S. V. (2013). Factors affecting job selection preferences of accounting students in Malaysian universities (Doctoral dissertation). Universiti Tunku Abdul Rahman.

Owusu, G. M. Y., Obeng, V. A., Ofori, C. G., Ossei Kwakye, T., \& Bekoe, R. A. (2018). What explains student's intentions to pursue a certified professional accountancy qualification? Meditari Accountancy 
Research, 26(2), 284-304.

Pratama, A. (2017). Why do accounting students choose a career in accountancy? An exploratory study in Bandung City, West Java, Indonesia. Review of Integrative Business and Economics Research, 6(2), 393-407.

Priyanti, L. G. D., Herawati, N. T., \& Sinarwati, N. I. K. (2017). Analisis faktor-faktor yang mempengaruhi pemilihan karir akuntan profesional dalam menghadapi Asean Economic Community (studi empiris pada mahasiswa jurusan akuntansi program S1 pada Universitas Negeri di Bali). JIMAT (Jurnal Ilmiah Mahasiswa Akuntansi) Undiksha, 7(1), 1-12.

Ragusa, G. (2017). Research shows how Generation Z thinks differently from millennials when it comes to money. Retrieved August 15 2018 from https:// www.businessinsider.com/differences-betweengeneration-z-and-millennials-money-2017-6/?IR=T

Santos, E. A. D., \& Almeida, L. B. D. (2018). To pursue a career in accounting or not: A study based on the theory of planned behavior. Revista Contabilidade \& Finanças, 29(76), 114-128.
Sari, M. (2014). Faktor-faktor yang mempengaruhi pemilihan karir menjadi akuntan publik oleh mahasiswa Departemen Akuntansi Fakultas Ekonomi UMSU Medan. Jurnal Riset Akuntansi dan Bisnis, 13(2), 174-201.

Schoenfeld, J., Segal, G., \& Borgia, D. (2017). Social cognitive career theory and the goal of becoming a certified public accountant. Accounting Education, 26(2), 109-126.

Singh, A. P., \& Dangmei, J. (2016). Understanding the Generation Z, the future workforce. South-Asian Journal of Multidisciplinary Studies, 3(3), 1-5.

Sugahara, S., Hiramatsu, K., \& Boland, G. (2009). The factors influencing accounting school students' career intention to become a certified public accountant in Japan. Asian Review of Accounting, 17(1), 5-22.

Wen, L., Hao, Q., \& Bu, D. (2015). Understanding the intentions of accounting students in China to pursue certified public accountant designation. Accounting Education, 24(4), 341-359.

World Bank Group. (2014). Current status of the accounting and auditing profession in Asean countries. Retrieved October $15^{\text {th }} 2017$ from www.aseanaccountant.org 